\title{
IAMJ
}

INTERNATIONAL

AYURVEDIC

MEDICAL JOURNAL

\section{CLINICAL STUDY TO EVALUATE THE EFFICACY OF AMALAKI RASAYAN AND MUKTA PISHTI IN PITTA SHAMAN - A RESEARCH ARTICLE}

\section{$\underline{\text { Sukhdev Khatotra }}^{1}, \underline{\text { Samiksha Sharma }}^{2}$}

${ }^{1}$ Assistant Professor, ${ }^{2}$ P.G Scholar

(P.G Department of Kayachiktsa, Jammu Institute of Ayurveda and Research, Jammu), India

Corresponding Author: samikshasharma2306@gmail.com

\section{https://doi.org/10.46607/iamj0109082021}

(Published Online: August 2021)

Open Access

(C) International Ayurvedic Medical Journal, India 2021

Article Received: 02/07//2021 - Peer Reviewed: 11/07/2021 - Accepted for Publication: 15/07/2021

\section{Check for updates}

\begin{abstract}
Owing to a busy lifestyle and wrong eating habits, the disease of Annavahasrotas is common in the present era. Acharaya Kashyap has accepted the involvement of three Doshas while Madhavkar accepted the dominance of pitta in this disease. Acharya Charak has not mentioned it as a separate disease but as one of the symptoms. The present study aimed to find out the efficacy of Amalaki Rasayan and Mukta Pishti in Amlapitta. A total of 30 patients were taken in three equal groups. Group A of 10 patients was treated with oral administration of Amalaki rasayan, in group B 10 patients were treated with Mukta Pishti and in group C 10 patients were treated with both. After conducting a clinical trial on 30 patients, observations and results were obtained.
\end{abstract}

Keywords: Amlapitta, Amalaki Rasayan, Mukta Pishti

\section{INTRODUCTION}

The word 'Amlapitta' is comprised of two words 'amla' and 'pitta'(gastric juice). In Amlapitta the quantity of Pachak Pitta is increased, its quality normal, bitter taste is changed to more sour taste as a result of fermentation, because of this increased sour quality of pitta it is called Amlapitta. Stress, strain, anxiety, improper food habits, accelerate the citation of Dosha by disturbing the action of Agni. Pitta dosha in the 
body is responsible for the production of dhatu, for digestion, helps in vision, regulates body temperature and complexion controls all systems big body and acts as a cognitive factor. It may become unbalanced due to pitta prakopa ahara and Vihara._Madhur, tikta, kashaya, cold drugs and activities cool the body and pacify the vitiated pitta dosha. Amalaki rasayan and mukta pishti both have properties to pacify pitta dosha that's why considered as the treatment of pitta prakopa vikara because they discontinue pathological series (samprapti vighatan) and stop changing the process of presumptions into symptoms.

\section{AIM AND OBJECTIVES:}

Comparative study on the efficacy of Amalaki Rasayan and Mukta pishti in the management of pitta vriddhikar disorders and on symptoms of pitta prakopa.

\section{MATERIALS AND METHODS}

\section{1) SELECTION OF THE PATIENT:}

The concealing strategies were held in OPD and IPD of Jammu Institute of Ayurveda and Research, Jammu. Patients having complaints of pitta prakopa or related disorders.

\section{2) GROUPING OF THE PATIENTS:}

A total of 30 patients were registered for the study and grouped under three based on the drug administration. Group A - This group of 10 patients were scheduled with Amalaki Rasayan,

Group B -This group of 10 patients were scheduled with Mukta pishti.

Group C - This group of 10 patients were scheduled with Amalaki Rasayan and Mukta pishti.

\section{3) DRUG DESCRIPTION:}

Amalaki Rasayan and Mukta pishti both have drugs with mild potency (sheet virya) and sweetish digestion (madhur vipaka) which helps to pacify tridosha. Specially Amalaki Rasayan fruit is a laxative that helps to clean out the excessive pitta Dosha from the body (virechana is the treatment of pitta prakopa) and is tonic which helps to nourish the body when excessive Pitta demands over nourishment otherwise can damage the soft tissues or mucous membranes of body channels. The fruit of Emblica Officinalis is useful in acid peptic ulcers and non-ulcer dyspepsia. Mukta(pearl) possess anti acidic, refrigerant, and tonic properties.

\section{4) DOSE AND DURATION OF DRUGS:}

2 grams of Amalaki Rasayan were administered with the Anupana of Madhu twice a day i.e., morning and evening, whereas $125 \mathrm{mg}$ of Mukta pishti were administered with water twice a day, till 30 days of the duration.

\section{RESULTS:}

Symptoms of pitta pakopa and their related disease were assessment factors for the study, the outcome after the drug administration showed the comparative effect of both drugs on the various complaints, reported by the patients.

\section{DISCUSSION}

Sex incidences of screened patients were showed high prevalence in male than female 20: 10, maybe due to excessive physical and mental exercise performed by males and have a tendency to express more anger, which is one of the main causative stimulations to enhance the pitta Dosha, Occurrence of pitta vriddhi were found more in between the age group of 16 year - 30 year, which reflects more apprehension in the middle age group as mentioned in Ayurveda. All selected patient belongs to Hindu community, this factor does not show the high incidences among Hindus, area of screening was belonging to Hindu locality. A maximum number of cases were related to educational occupation or were highly educated, excessive mantel exercise, tension, the pressure of studies and worries can produce the symptoms of pitta prakopa.

Addiction to tea, coffee or tobacco may also cause pitta prakopa and its related diseases. Person of pitta prakriti has mridu koshtha (mild), are vulnerable to pitta vikara. Because samagni (uniform) is sensitive to become vishama Agni (alter), the census of cases support that, the maximum number of patients were found from the group of pitta prakriti and of Sama Agni. 
Table 1

\begin{tabular}{|c|c|c|c|c|c|c|c|c|c|c|}
\hline \multirow{2}{*}{ S.No. } & \multirow{2}{*}{ Symptoms } & \multicolumn{3}{|c|}{ Group A } & \multicolumn{3}{|c|}{ Group B } & \multicolumn{3}{|c|}{ Group C } \\
\hline & & B.T. & A.T. & $\underset{\%}{\text { Imp. }}$ & B.T. & A.T. & $\underset{\%}{\text { Imp. }}$ & B.T. & A.T. & Imp. \% \\
\hline 1. & $\begin{array}{l}\text { Amlaka } \\
\text { (Acid eructation) }\end{array}$ & 8 & 2 & $75.00 \%$ & 6 & 1 & $83.33 \%$ & 9 & 1 & $88.88 \%$ \\
\hline 2. & $\begin{array}{l}\text { Atripti } \\
\text { (nonsatisfaction) }\end{array}$ & 3 & 1 & $66.66 \%$ & 5 & 1 & $80.00 \%$ & 8 & 1 & $87.50 \%$ \\
\hline 3. & $\begin{array}{l}\text { Trishna adhikya } \\
\text { (Excessive thirst) }\end{array}$ & 6 & 2 & $66.66 \%$ & 7 & 2 & $71.42 \%$ & 7 & 2 & $71.42 \%$ \\
\hline 4. & $\begin{array}{l}\text { Tikta asyata } \\
\text { (Bitter taste) }\end{array}$ & 9 & 3 & $66.66 \%$ & 7 & 1 & $85.71 \%$ & 9 & 1 & $88.88 \%$ \\
\hline 5. & $\begin{array}{l}\text { Ushma adhikya } \\
\text { (Over hotness) }\end{array}$ & 5 & 2 & $60.00 \%$ & 4 & 3 & $25.00 \%$ & 9 & 2 & $77.77 \%$ \\
\hline 6. & $\begin{array}{l}\text { Sweda atipravriti } \\
\text { (Excessive } \\
\text { sweating) }\end{array}$ & 3 & 2 & $33.33 \%$ & 4 & 2 & $50.00 \%$ & 5 & 2 & $60.00 \%$ \\
\hline 7. & $\begin{array}{l}\text { Gatra } \\
\text { daurgandhyam } \\
\text { (Disagreeable } \\
\text { smell) }\end{array}$ & 5 & 3 & $60.00 \%$ & 2 & 2 & $00.00 \%$ & 6 & 3 & $50.00 \%$ \\
\hline 8. & $\begin{array}{l}\text { Kantha shoushta } \\
\text { (choking) }\end{array}$ & 7 & 2 & $71.40 \%$ & 9 & 2 & $77.77 \%$ & 8 & 4 & $50.00 \%$ \\
\hline 9. & $\begin{array}{l}\text { Raktasphota (Red } \\
\text { vesicle) }\end{array}$ & 3 & 1 & $66.66 \%$ & 3 & 2 & $33.33 \%$ & 7 & 4 & $42.85 \%$ \\
\hline 10. & $\begin{array}{l}\text { Raktamandala } \\
\text { (Red wheals) }\end{array}$ & 7 & 5 & $28.57 \%$ & 3 & 2 & $33.33 \%$ & 8 & 3 & $62.50 \%$ \\
\hline 11. & $\begin{array}{l}\text { Asyapaka } \\
\text { (Stomatitis) }\end{array}$ & 7 & 2 & $71.4 \%$ & 6 & 1 & $83.33 \%$ & 7 & 3 & $57.14 \%$ \\
\hline 12. & Ausha (Heating) & 4 & 2 & $50.00 \%$ & 5 & 1 & $80.00 \%$ & 6 & 2 & $53.33 \%$ \\
\hline 13. & $\begin{array}{l}\text { Plosha } \\
\text { (Scorching) }\end{array}$ & 5 & 4 & $20.00 \%$ & 4 & 2 & $50.00 \%$ & 5 & 1 & $80.00 \%$ \\
\hline 14. & $\begin{array}{l}\text { Antardaha } \\
\text { (Burning } \\
\text { sensation inside } \\
\text { the body) }\end{array}$ & 2 & 1 & $50.00 \%$ & 4 & 1 & $25.00 \%$ & 6 & 2 & $66.66 \%$ \\
\hline 15. & $\begin{array}{l}\text { Davathu } \\
\text { (Boiling) }\end{array}$ & 5 & 4 & $40.00 \%$ & 3 & 3 & $00.00 \%$ & 6 & 3 & $50.00 \%$ \\
\hline 16. & Arti (Uneasiness) & 6 & 2 & $66.66 \%$ & 6 & 3 & $50.00 \%$ & 3 & 0 & $100.00 \%$ \\
\hline 17. & $\begin{array}{l}\text { Klama } \\
\text { (Tiresome) }\end{array}$ & 5 & 4 & $20.00 \%$ & 4 & 3 & $25.00 \%$ & 6 & 1 & $83.33 \%$ \\
\hline 18. & $\begin{array}{l}\text { Nishatva } \\
\text { (Irritation) }\end{array}$ & 6 & 4 & $33.33 \%$ & 5 & 4 & $20.00 \%$ & 7 & 2 & $71.42 \%$ \\
\hline 19. & $\begin{array}{l}\text { Alpanidra } \\
\text { (Sleeplessness) }\end{array}$ & 7 & 2 & $71.40 \%$ & 6 & 1 & $83.33 \%$ & 3 & 1 & $66.66 \%$ \\
\hline 20. & $\begin{array}{l}\text { Sheeta abilasha } \\
\text { (Desire for } \\
\text { coolness) }\end{array}$ & 6 & 2 & $66.66 \%$ & 3 & 1 & $66.66 \%$ & 5 & 1 & $80.00 \%$ \\
\hline 21. & $\begin{array}{l}\text { Madhur sheeta } \\
\text { (kashaya } \\
\text { Abilasha) }\end{array}$ & 1 & 1 & $00.00 \%$ & 4 & 4 & $00.00 \%$ & 5 & 1 & $80.00 \%$ \\
\hline
\end{tabular}




\section{CONCLUSION}

Group A showed 54.54\%, Group B showed 58.41\%, Group C showed $70.37 \%$ favourable results to pacify the pitta prakopa. Statistical observations represent the 'to the valve of Group $A=12.73$, Group $B=11.70$ and of Group $\mathrm{C}=15.80 \%$. The comparison between the results of both drugs favours best Mukta pishti as compared to Amalaki, Rasayan, but the combined effect of both drugs found the best outcome on pitta vriddhi. Amalaki Rasayan showed the best response on acid education (75\%) and the least response on the desire of Madhur, tikta kashaya dravya. Mukta pishti showed the best response in bitterness of buccal mucosa $(85.71 \%)$ and least response on disagreeable smell, boiling, desire to have Madhur tikta kashaya articles (0\%). Both drugs combined have a good response on arti (uneasiness) $100 \%$ and the least effect on red vesicles $(42.85 \%)$. Because both drugs have physical properties in contrast to the intensity of pitta (Agni) i.e. cold, madhur vipaka and also they both were formulated, either with the same compound. That's why this suggests appropriation of both drugs on pitta vriddhi, and various disorders related to pitta.

\begin{tabular}{|c|c|c|c|c|}
\hline GROUP & PERCENTAGE & $\mathrm{D}$ & S.E & $\mathrm{t}$ value \\
\hline A & $54.5 \%$ & 1.490 & 0.471 & 12.73 \\
\hline B & $58.41 \%$ & 1.595 & 0.504 & 11.70 \\
\hline $\mathrm{C}$ & $70.37 \%$ & 1.900 & 0.601 & 15.80 \\
\hline
\end{tabular}

\section{REFERENCES}

1. Agnivesha Charak Samhita, Ayurveda Deepika Sanskrit Tippani Chakrapani Chaukhamba Sanskrita Series Varanasi, 1991.

2. Sushruta Samhita, Dalhana Tika Chaukhamba Sanskrita Series Varanasi, 1986.

3. Vagbahatta, Ashtangasangraha,Indu Tika Chowkhamba Varanasi,1986.Chaukamba

4. Kashyapa, Kashyapa Samhita, Sharma H, Editor, Vidyotini. Khila Stana. Chaukamba Sanskrit Sanstana; 2009, Chap 16, Slk 9.

5. Chakrapanidatta. Chakradutta, Savimarsha Vaidyaprabha. Tripati I, Editor, Varanasi: Chaukamba Sanskrit Sanstana, 2002., Chap 15, Slk 45-49

6. Madhavakara, Madhava Nidana, Part 2nd With Madhukosha Sanskrit. Tripati B, Editor. Varanasi Chukamba Surabharati Prakashana, 2002, Chap 51, Slk 2
7. Shri Govind Dasaji, Kaviraj Shri Ambikadutta Shastri, Bhaishajya Ratnavali, Varanasi Chukamba Surabharati Prakashana 2009, Chap 56, Slk 21.

8. Sharma PV. Dravyaguna Vignana, Part II, Chaukamba. Varanasi: Bharati Academy

\section{Source of Support: Nil \\ Conflict of Interest: None Declared}

How to cite this URL: Sukhdev Khatotra \& Samiksha Sharma: Clinical Study To Evaluate The Efficacy Of Amalaki Rasayan And Mukta Pishti In Pitta Shaman - A Research Article. International Ayurvedic Medical Journal \{online\} 2021 \{cited August 2021\} Available from: http://www.iamj.in/posts/images/upload/1608_1611.pdf 